University of Michigan Law School

University of Michigan Law School Scholarship Repository

Articles

Faculty Scholarship

1996

\title{
The Cosmological Question: A Response to Milner S. Ball's 'All the Company of Heaven'
}

Joseph Vining

University of Michigan Law School, jvining@umich.edu

Available at: https://repository.law.umich.edu/articles/1626

Follow this and additional works at: https://repository.law.umich.edu/articles

Part of the Law and Philosophy Commons, Religion Law Commons, and the Science and Technology Law Commons

\section{Recommended Citation}

Vining, Joseph. "The Cosmological Question: A Response to Milner S. Ball's 'All the Company of Heaven'." Mich. L. Rev. 94, no. 6 (1996): 2024-8.

This Response or Comment is brought to you for free and open access by the Faculty Scholarship at University of Michigan Law School Scholarship Repository. It has been accepted for inclusion in Articles by an authorized administrator of University of Michigan Law School Scholarship Repository. For more information, please contact mlaw.repository@umich.edu. 


\title{
THE COSMOLOGICAL QUESTION \\ A Response to Milner S. Ball's All the Company of Heaven
}

\author{
Joseph Vining*
}

We do not disagree, and I do not doubt, that legal processes are sources of injustice, violent oppression, crushing of the spirit, destruction of lives, actual death. I have only to look at The Trial ${ }^{1}$ again. Nor do we disagree that there are strings of words, statements, put out by officials, lawyers, and lawyer-academics, often called "rules," that cannot be taken into oneself and that by their very nature evoke manipulation in response, avoidance if they cannot be ignored. In their name violent imposition of pure will occurs all the time, and power is exercised by those who can secure for the moment some obedience.

Though we have different words for the poles and the possibilities, I know we do not disagree about this. For me, this is the authoritarian - there is much in the phrase "in the name of the law" with which I began my last book. The authoritarian is dead, not in the sense of not being there, but in the sense of being merely material for manipulation, just there and no more than there. Perhaps because of the difference between the areas of law in which we work, you see the oppression, the deadening, the success of efforts to use and control. I tend to see, in organizational law, successful evasion of them, reduction of them to dead letter, escape.

Even when we are in good faith, there eventually rises in us all a tired reach for something solid and fated, so solid and fated that we have no part in creating it and therefore bear no responsibility for it. All of us recognize a tired sinking back from any reach, to the sense that the appearance of the moment is all that is real. All of us seek at some time to deny what makes law possible.

But this book is not so much addressing the question of the authoritarian, our own failure, which is a question internal to law. From Newton's Sleep takes up rather the question raised by looking out from law to what the world might be like if there were no law,

* Hutchins Professor of Law, University of Michigan. B.A. 1959, Yale; J.D. 1964, Harvard; M.A. 1970, Cambridge. - Ed.

1. Franz KafKa, The Trial (Willa Muir \& Edwin Muir trans., Alfred A. Kropf rev. ed. 1992) (1925). 
and more importantly, what the mental world would be like without even the possibility of law. I say "more importantly" following William James, who prefaced his Pragmatism with Chesterton's observation that "the most practical and important thing about a man is still his view of the universe. ... [T] he question is not whether the theory of the cosmos affects matters, but whether, in the long run, anything else affects them." 2

Our own Holmes echoed the point, and may be an example of it. You may remember his conclusion in his manifesto, The Path of the Law, urging lawyers to "connect your subject with the universe." 3 Pragmatists, both James and Holmes are thought to be, standing at the beginning of this extraordinary century; but James alone remained empirically minded. Holmes, on this matter that he, like James, thought most important, was not an empiricist. He began not with evidence but with a definition. Law, he said, was "like everything else" in the universe and "[t]he postulate on which we think about the universe is that there is a fixed quantitative relation between every phenomenon and its antecedents and consequents."4

What I hope some will do in the new century is begin with law, as part of the evidence to be read about our situation and our belief about our situation - not ignore law, not dogmatically reduce it, but read it as evidence in good empirical fashion. Evidence is always evidence of; looking to evidence is always pursuant to a question. You look at the evidence and see fallenness. I might respond, "Of course" - but go on to say that your question is internal, one which leaves intact those aspects of the world that allow you to speak of fallenness, including human language and human speaking. I would direct attention to the legal form of thought and its meaning, which at its broadest touches the cosmological question, our true sense of our own nature and the nature of the world.

When we open ourselves wholly to the evidence, what can we honestly say we truly believe? What can we honestly say others whom we hear speaking truly believe?

As you point out, any evocation or exposition of the legal form of thought will have a negative thrust in the context of the total claims made in cosmologies being widely advanced. When human law and the legal form of thought are placed in the same world of

2. William James, Pragmatism 9 (Harvard Univ. Press 1975) (1907) (quoting Gilbert K. Chesterton, Heretics 15-16 (2d ed. 1905)).

3. O.W. Holmes, Jr., The Path of the Law, 10 HaRv. L. REv. 457, 478 (1897).

4. Id. at 465. 
experience as scientific law and the mathematical or scientific form of thought, there is immediately a negative point being made - the incompatibility of legal thought and scientific or mathematical thought insofar as science or mathematics claims it is the only form of thought, that does or will explain all others or reduce all others to itself. There cannot be any exclusive claim for the mathematical or scientific form of thought, "cannot be" in various senses. And it is an advance to conclude what our situation cannot be, even if one does not achieve at once positive knowledge of what the situation is. The question is cosmological, and as James and Holmes knew starting the century off, the question is not merely academic. I would suppose that to be even clearer after the experience of this century - again, I think you would agree.

The point at which I pause, therefore, is where you say, "law does not save - from Newton's Sleep or death."5 This seems, at least seems, so much against any reader drawing the conclusion that the presence of law in the human mind, or of legal thought, does keep us from Newton's sleep, all of us and daily. "Save" and "keep" are different; "save" has much more in it - we can, of course, utterly fail. But you go on to say that "there is as much addictive sleep in law as there is in mathematical thought and as much waking good."6 Here we may part, unless your "sleep" is not "Newton's sleep."

Single vision, Newton's sleep, lies precisely in the total claims made for a form of thought that is in itself a good and, as you say, can lead to good. If the legal form of thought and the mathematical form of thought are to be put side by side, as you have them, for equal admiration and equal criticism, there cannot be an ultimacy about the latter and an exclusive truth in what it leads and permits one to see. Except that the reader's shelf and day may have no more room, I might urge that Jean-Pierre Changeux and Alain Connes's recent Conversations on Mind, Matter, and Mathematics ${ }^{7}$ be added to your suggestions of Bachman and Stringfellow, to provide a window directly on the claims of ultimacy being made today.

I would, of course, agree that the mathematical and the legal forms of thought be put side by side. That would be a first step toward a cosmology that does take into account the presence and

5. Milner S. Ball, All the Company of Heaven, 94 Mrch. L. REv. 2016, 2021 (1996) (book review).

6. Id.

7. Jean-Pierre Changeux \& Alain Connes, Conyersations on Mind, Matter, and Mathematics (M.B. DeBevoise ed. \& trans., 1995). 
experience of human law. I think the cosmology in the pages of From Newton's Sleep, or I should say beyond those pages, is compatible with the experience of mathematical truth and scientific truth, with their intrinsic and material rewards, their confirmations, reinforcements, uncanny matchings - with the continuing discovery of a generous responsiveness in the natural world. I see no incompatibility between yearning to understand systems or finding beauty in them, and acknowledging that the human is beyond system.

What I have tried to do in the book I would like to be taken, especially by you, less as celebrating law and lawyers and more as sketching and evoking the legal form of thought and its meaning, for the reader, and more generally for science and indeed religion. Science and religion have as much reason to look to law, as law has to look to science and religion. Where the question is our sense of the cosmos that includes us and all things, human law is part of the evidence; part of the way one can see what one does believe today about this, the cosmos that includes everything, is to become and remain aware of human law and the legal form of thought. Placing them beside scientific law and the scientific or the mathematical form of thought, in the same world of experience, leads us back to the task of reading ourselves. You and I as lawyers would not disagree that what we say is always only part of the evidence of what we actually believe. Everyone knows that is true in small matters. But the same is true in large matters, that for your actual belief - to go to the "you" at the end - you must and do look to all the evidence, even to judge the meaning of the words you use to say what you believe.

This is why the book can be said to be about the legal form of thought and its meaning today, rather than about exaltation of law into the "company of heaven," even "all the company of heaven." Cosmological speculation is intense at the end of this century, with good reason, and lawyers may make a contribution to it, odd though that may seem. I thought originally to set out at the start of From Newton's Sleep some examples of the problem of reading ourselves, or others. Let me set them out here as questions you and I or anyone, lawyer or nonlawyer, might pursue.

A group of physicists, satisfied that all in the universe is to be explained by the laws of physics and evolution, laugh, love, and care passionately about a sane world yet to be achieved. How are they to be read, or to read themselves? The sentences in which they profess their cosmology are only part of the evidence of their actual 
belief. A group of convinced atheists are moved by the Sanctus in Bach's $B$-minor Mass. Might this say something about them as well as about Bach and the music? A poet writes of total despair, absolute meaninglessness. But she writes, and writes a poem. What are we to make of the fact of the poem in seeking to understand her vision of the world? A society lives by law, and individuals in it invoke the authority of law in their everyday lives. What does this say of the society and the actual belief of individuals in it? What does this say of us ourselves, even the most sophisticated of us? 